\title{
Modeling and Simulation of PEM Fuel Cell Generator as a Micro Grid
}

\author{
Sukumar Kamalasadan \\ Chad M. Tanton \\ Department of Engineering and Computer Technology \\ University of West Florida, 11000 University Parkway \\ Pensacola, FL 32514, USA \\ skamalasadan@uwf.edu \\ cmt23@students.uwf.edu
}

\begin{abstract}
This paper describes an integrated model for a Photon Exchange Membrane (PEM) fuel cell generator including the power conditioning devices that can be used as a micro grid. The main focus here is the development of a detailed model of the fuel cell, power conditioning devices and a Voltage Source Inverter (VSI) with no major assumptions. To this end nonlinear models for PEM fuel cell generator, power conditioning devices and controllers are designed and built in Matlab ${ }^{\circledR}$ and Simulink ${ }^{\circledR}$ and the integrated designs are validated. Then several case studies are performed to operate the proposed integrated model as a microgrid. Overall vision is to validate this model with real-life system and generate smart controller for the micro-grid that could be implemented in real-time as a Distributed Generator (DG).
\end{abstract}

Keywords-component; PEM Fuel cell, DC/DC Converter, VSI Inverter, Micro-grid, Smart-Grid, Distributed Generator (DG)

\section{NOMENCLATURE}

Parameter

Number of Cells per Stack $\left(\mathrm{N}_{\mathrm{o}}\right)$

Number of Stacks ( $\mathrm{N}_{\text {stack }}$ )

Faraday's Constant (F)

Utilization Factor (U)

$\mathrm{k}_{3}$ constant $=1 /(2 \mathrm{CV})$

Reformer Time Constant $\left(\tau_{1}\right)$

Reformer Time Constant $(\tau 2)$

PI Controller Time Constant ( $\tau 3)$

Conversion Factor (CV)

Methane Reference Signal ( $\left.\mathrm{q}_{\text {methref }}\right)$

Hydrogen-Oxygen Flow Ratio $\left(\mathrm{r}_{\mathrm{H}-\mathrm{O}}\right)$

$\mathrm{k}_{\mathrm{r}}$ constant $=\mathrm{No} /(2 \mathrm{~F})$

Stack Internal Resistance $\left(\mathrm{R}^{\mathrm{int}}\right)$

Activation Voltage Constant (B)

Ohmic Resistance Inside Cell ( $\left.\mathrm{R}_{\mathrm{ohm}}\right)$

Constant Factor $\left(\lambda_{e}\right)$

Overall Flow Delay $\left(\tau_{\mathrm{e}}\right)$

Activation Voltage Constant (C)

Hydrogen Valve Constant $\left(\mathrm{K}_{\mathrm{H} 2}\right)$

Oxygen Valve Constant $\left(\mathrm{K}_{\mathrm{O} 2}\right)$

Water Valve Constant $\left(\mathrm{K}_{\mathrm{H} 2 \mathrm{O}}\right)$

Hydrogen Time Constant $\left(\tau_{\mathrm{H} 2}\right)$

Oxygen Time Constant $\left(\tau_{\mathrm{O} 2}\right)$

Water Time Constant $\left(\tau_{\mathrm{H} 2 \mathrm{O}}\right)$

Standard No Load Voltage $\left(E_{o}\right)$

Universal Gas Constant (R)

Stack Temperature (T)

Line Reactance (X)

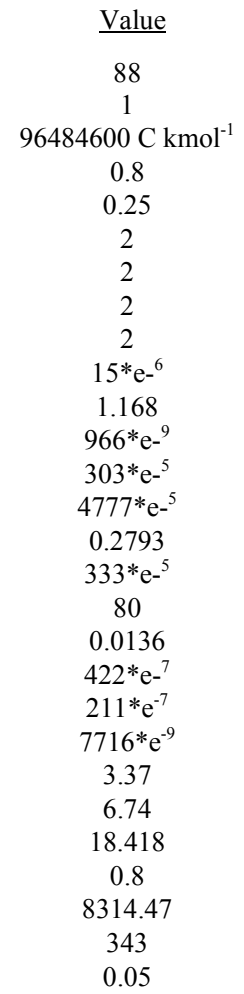

Source Voltage $\left(\mathrm{V}_{\mathrm{s}}\right)$

PI Gain Constants $\left(\mathrm{k}_{5}, \mathrm{k}_{6}\right)$

Empirical Constant ( $\left.\mathrm{k}_{\mathrm{RI}}\right)$

Empirical Constant $\left(\mathrm{k}_{\mathrm{RT}}\right)$

\section{INTRODUCTION}

A fuel cell generator in the form of a micro grid can be represented as shown in fig. 1 block diagram. Main components consist of fuel cell stack, power conditioning devices such as DC/ DC Converters and inverter with controllers for fuel cell and VSI Inverter. Each of these blocks is discussed next.

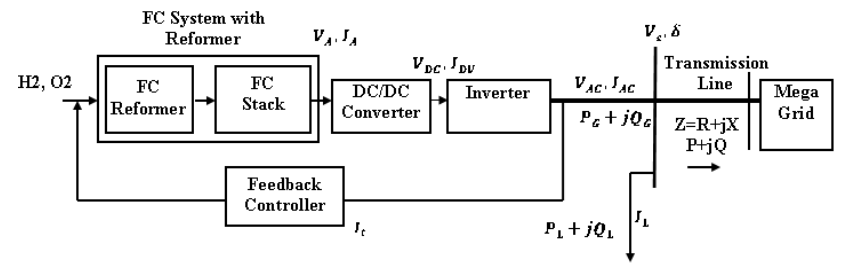

Figure 1. Block diagram of a fuel cell generator

\section{A. Fuel Cell Generator}

A PEM Fuel Cell is comprised of two main components, the reformer and fuel cell stack. The reformer is the component that takes hydrocarbons, in most cases, such as methanol or propane and separates the hydrogen molecules from the gases and injects that into the anode side of the fuel cell stack. In the anode, hydrogen is forced through a catalyst, usually made of platinum, which separates the hydrogen molecules into electrons and protons. The protons are allowed to permeate through a proton conducting polymer membrane called a Proton Exchange Membrane (PEM), which separates the anode and cathode. The electrons are forced around the electrically insulated PEM through an external circuit which in turn supplies electrical power to it. An elementary block diagram is given in fig. 2. Several models have been proposed for the fuel cell [1]-[12]. However, most of these models shows the basic equations for the fuel cells with some assumptions or do not consider the power conditioning devices to use this system as a micro grid. The proposed model of the fuel cell is an electromechanical one with no major assumptions and reflecting the nonlinear relation between chemical reactions in the fuel cell. Also the model presented here is based on 
simulating the relationship between output voltage and partial pressures of hydrogen, oxygen, and water. It gives insight to the transient and linear response of a PEM fuel cell with a generating capacity of one thousand watts.

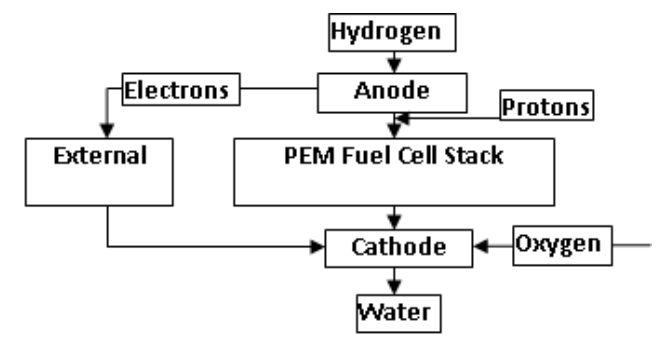

Figure 2. Elementary flow block diagram of a PEM fuel cell

In fig. 2, the reformer provides relatively pure hydrogen to the fuel cell, using a hydrocarbon that is readily available such as methanol, propane, or natural gas to name a few. For houses and stationary power generation, fuels like natural gas or propane are preferred, simply because many power generator stations and houses are already hooked up to natural gas supplies by pipeline or have propane tanks on the property.

However, this paper discusses methanol reforming because methane has a higher energy density and is easier to transport. The process starts with the vaporization of liquid methanol and water. Heat produced in the reforming process is used to accomplish this. This mixture is passed through a heated chamber that contains a catalyst. As the methanol molecules hit the catalyst, they split into carbon monoxide (CO) and hydrogen gas $\left(\mathrm{H}_{2}\right)$. The water vapor splits into hydrogen gas and oxygen; this oxygen combines with the $\mathrm{CO}$ to form $\mathrm{CO}_{2}$. It is important to eliminate as much of the $\mathrm{CO}$ from the exhaust gas, and this way, very little CO is released, as most of it is converted to $\mathrm{CO}_{2}$.

\section{B. DC/DC Convertor}

Most models for fuel cells usually neglect the effect of DC/DC converters [13]. We propose in this paper the state space model and transfer functions for the combination of PEM fuel cell and related DC/DC Converter. The DC/DC converter developed was designed using the small signal state space model for the boost DC/DC Converter evolved from [14]. The introduced model is a multivariable one with two inputs and outputs, as in fig. 3.

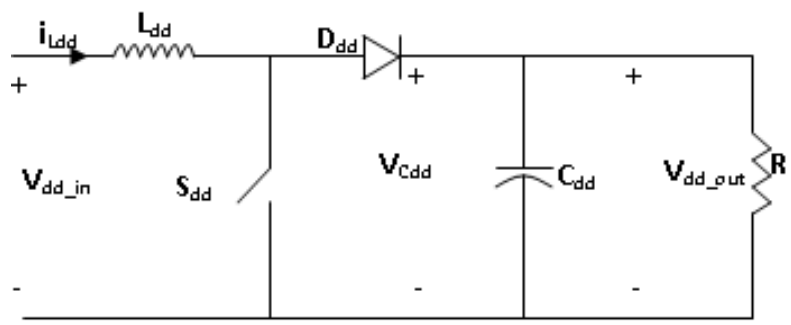

Figure 3. Boost DC/DC converter

This convertor contains one control signal which is used to shape the duty cycle. The traditional PWM to calculate the duty cycle is not needed in this model because of a feedback loop used to calculate the duty cycle.

\section{DC/AC Inverter}

For larger power applications of a fuel cell the output of a generator would need to be connected to an AC load. In order to do this an inverter is needed. Several studies [15], [16]-[18] have shown that the switching function concept is a powerful tool in understanding and optimizing the performance of the inverter. Using the switching function concept, the power conversion circuits can be modeled according to their functions rather than circuit topologies. Therefore, it can achieve simplification of the overall power conversion functions. The inverter can be modeled as a black box with the input and output ports. The dc and ac variables can be input and output according to the operation mode. Then a transfer function is developed to describe the task to be performed by the circuits. In this paper, the sinusoidal PWM (SPWM) technique is considered as a control strategy. Based on the SPWM (fig. 4.), two switching functions are required for a Voltage Source Inverter (VSI).

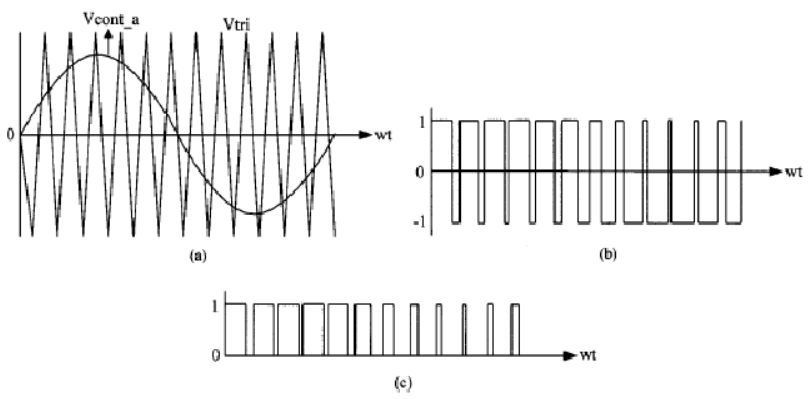

Figure 4. (a) Carrier and control signals (b) Switching function $1\left\{\mathrm{SF}_{1}\right\}$ (c) Switching function $2\left\{\mathrm{SF}_{2}\right\}$

\section{Fuel Cell Generator and VSI with Controllers}

The main function of a fuel cell and VSI controller will be to sense a load demand and provide a feedback current for fuel cell reformer to determine how much hydrogen to send forward to the fuel cell stack. This is a feedback loop that has to be completed for the fuel cell to know how much power to put out into the power system. The VSI controller mainly controls the output voltage based on the fuel cell controller (controls the stack current based on the load) in an outer loop manner. In this work, we introduce two main controllers, one based on VSI and the other for fuel cell. The controllers interact with each other and perform smart functions for the proposed DG based micro grid. The purpose of these controllers is to use it as a load following options in the presence of using this micro grid in a hybrid mode.

This paper is organized as follows: Section III presents the mathematical formulations used to create the model. Section IV presents the simulation results that were obtained using MATLAB $^{\circledR}$ and Simulink ${ }^{\circledR}$, Section V illustrates the use of fuel cell generator as a micro grid and Section VI concludes the paper. 


\section{MATHEMATICAL FORMULATION}

\section{A. Fuel Cell Generator}

The fuel cell system is continuously consuming hydrogen and the reformer is continuously generating hydrogen according to power demand. To model a reformer a secondorder transfer function as in (1) is developed.

$$
\frac{q_{H 2}}{q_{\text {methanol }}}=\frac{C V}{\tau_{1} \tau_{2} s^{2}+\left(\tau_{1}+\tau_{2}\right) s+1}
$$

Controlling the hydrogen flow rate, according to power demand, is essential to the operation of a fuel cell system. A Proportional Integral (PI) controller is introduced to the system to control the hydrogen, oxygen, and water vapor flow rates. This feedback control is designed by taking the fuel cell output current and feeding it back to the input while converting the hydrogen into molar form based on (2)-(12):

The relationship between the hydrogen flow and the feedback current can be represented as

$$
q_{H 2}=\frac{N_{O} I}{2 F U}
$$

The proposed PI controller is used to calculate the amount of hydrogen needed from the reformer which is used to determine the methane flow rate into the reformer. This can be expressed as:

$$
q_{\text {methanol }}=\left(k_{3}+\frac{k_{3}}{\tau_{3} s}\right)\left(\frac{\mathrm{N}_{\mathrm{o}} \mathrm{I}}{2 \mathrm{FU}}-\mathrm{q}_{\mathrm{H} 2}+\mathrm{q}_{\text {methref }}\right)
$$

Mathematical representation of the oxygen flow rate can be seen below:

$$
q_{O 2}=\frac{1}{\mathbf{r}_{H-O}}
$$

In this model, dependence on the partial pressures of hydrogen, oxygen, and water vapor is introduced for the fuel cell stack. Some additional parameters are also used to get the model highly accurate and nonlinear. Following assumptions are made for the development of the model:

1. The operating fuel cell temperature will remain under $373 \mathrm{~K}$

2. The reaction product entering the reformer is in the liquid phase.

3. The fuel cell stack output voltage can be obtained by lumping together the individual cell parameters to represent a fuel cell stack

4. In the fuel cell and the gas flow channels the pressures are kept constant.

5. Both the hydrogen and oxidants are humidified to prevent damage to the proton exchange membrane.

According to assumptions 3 and 4, the fuel cell output voltage can be obtained by the sum of the Nernst voltage, the activation over voltage, the ohmic over voltage and the concentration over voltage. The mathematical representation of this detailed model is as shown in (5)-(9):

$$
V_{\text {cell }}=E-V_{a c t}-V_{o h m}-V_{c o n c}
$$

where,

$$
\begin{gathered}
V_{\text {conc }}=\frac{R T}{z F} \ln \left(1-\frac{I}{I_{\text {limit }}}\right) \\
V_{\text {ohm }}=I\left(R_{\text {ohm } 0}+k_{R I} I-k_{R T} T\right) \\
V_{a c t}=-B \ln (C I) \\
E=E_{o}+\frac{R T}{2 F} \ln \left[p_{H 2}\left(p_{O 2}\right)^{0.5}\right]-E_{d}
\end{gathered}
$$

To calculate $E$ properly, $E_{d}$ is used which is the reversible voltage delay. This delay is considered because of the time delay of the fuel and oxidant. Under steady state conditions, $E_{d}$ is equal to zero due to the fact that the fuel and oxidants are in steady state. Also, notable in the equation above are the partial pressures of hydrogen and oxidants. These are used to help account for the delay of the hydrogen and oxidants. The three mathematical representation of this delay can be seen below:

$$
\begin{array}{r}
E_{d}=\lambda_{e} I\left(\frac{\tau_{e} s}{\tau_{e} s+1}\right) \\
p_{H 2}=\frac{I}{k_{H 2}}\left(\frac{\tau_{H 2} s}{\tau_{H 2} s+1}\right) \\
p_{O 2}=\frac{I}{k_{O 2}}\left(\frac{\tau_{O 2} s}{\tau_{O 2} s+1}\right)
\end{array}
$$

\section{B. DC/DC Converter}

As discussed, the small signal state space model of the boost DC/DC converter can be obtained by using the following equations.

$$
\left[\begin{array}{c}
\frac{d i_{t}}{d t} \\
\frac{d v_{t}}{d t}
\end{array}\right]=\left[\begin{array}{cc}
0 & \frac{-(1-D)}{L} \\
\frac{1-D}{C} & \frac{-1}{R C}
\end{array}\right] *\left[\begin{array}{c}
i_{L} \\
v_{C}
\end{array}\right]+\left[\begin{array}{c}
\frac{v_{C}}{L} \\
\frac{-i_{L}}{C}
\end{array}\right] * U
$$

When solved for current and voltage in the frequency domain, results are as follows:

$$
\begin{gathered}
i_{L}=\left(\frac{-v_{C}(1-D)}{L}+\frac{v_{C}}{L} U\right) \frac{1}{s} \\
v_{C}=\left(\frac{i_{L}(1-D)}{C}-\frac{v_{C}}{R C}-\frac{i_{L}}{C} U\right) \frac{1}{S}
\end{gathered}
$$

Additionally switching losses and input port series resistance were incorporated in this model. The output current and voltage is calculated based on [13] in order to show the switching current losses and the input port series resistance voltage losses for the converter. 


$$
\begin{gathered}
v_{O}=v_{C}-v_{R L} \\
i_{O}=\frac{v_{c e l l}(1-D)}{R_{L}}-\frac{v_{O}(1-D)^{2}}{R_{L}}-I_{s w}
\end{gathered}
$$

A varying duty cycle is used in this model to ensure that the output is constant. To ensure that the model was achieving a high efficiency, an algorithm for calculating efficiency with a varying duty cycle is used [16].

$$
E f f=\frac{1}{1+\frac{R_{L} i_{O}}{(1-D)^{2} v_{O}}}
$$

To achieve higher efficiency, the capacitor and inductor values are calculated using the following equation.

$$
\begin{gathered}
L=\frac{I_{\text {ref }}}{2 f I_{\text {Omax }}} D_{\max }(1-D)^{2} \\
C=\frac{I_{\text {ref }} D_{\max }}{f V_{\text {ripple }}}
\end{gathered}
$$

Where,

$$
D_{\max }=1-\frac{V_{\max }}{V_{\text {ref }}}
$$

Using these equations to find the appropriate inductor and capacitor values is critical in building a boost converter that is both functional and efficient.

\section{Three Phase Inverter}

A three phase DC/AC inverter with switches and diodes takes a constant DC voltage input and inverts that into three phases of $\mathrm{AC}$ voltage. It can be configured as in fig. 5: Two switching functions $\mathrm{SF}_{1}$ and $\mathrm{SF}_{2}$ are used to design $\mathrm{S}_{1}-\mathrm{S}_{6}$ indicated in fig. 5. The switching function $\mathrm{SF}_{1}$ expresses the $\mathrm{V}_{\mathrm{ao}}, \mathrm{V}_{\mathrm{bo}}$, and $\mathrm{V}_{\text {co }}$ and it is used to calculate the inverter line-toline voltages $\left(\mathrm{V}_{\mathrm{ab}}, \mathrm{V}_{\mathrm{bc}}, \mathrm{V}_{\mathrm{ca}}\right)$ and phase voltages $\left(\mathrm{V}_{\mathrm{an}}, \mathrm{V}_{\mathrm{bn}}, \mathrm{V}_{\mathrm{cn}}\right)$. On the other hand, the switching function $\mathrm{SF}_{2}$ designates the voltage across the switch and the load currents $\left(I_{a}, I_{b}, I_{c}\right)$ are derived as ratios of voltages and respective impedances using the switching function $\mathrm{SF}_{2}$. Mathematical representations and are given as follows:

$$
\begin{gathered}
S F_{1}=\sum_{n=1}^{\infty} A_{n} \sin (n \omega t) \\
S F_{2}=B_{o}+\sum_{n=1}^{\infty} B_{n} \sin (n \omega t)
\end{gathered}
$$

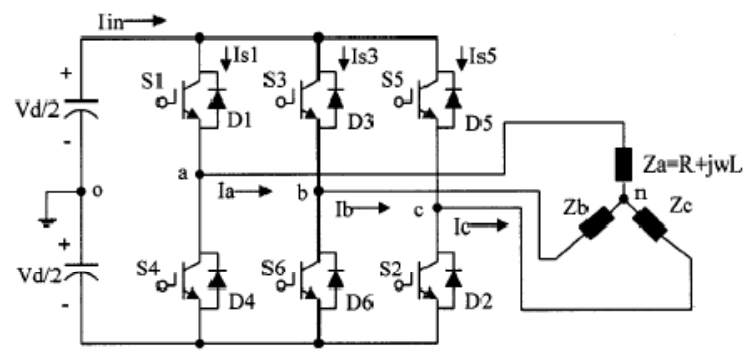

Figure 5. Circuit configuration of a three phase voltage source inverter
Each switching function has three phases (a, b, and c) all 120 degrees apart. Using the switching function $\mathrm{SF}_{1 \mathrm{a}, \mathrm{b}, \mathrm{c}}$ the $\mathrm{V}_{\mathrm{ao}}$, $\mathrm{V}_{\mathrm{bo}}$, and $\mathrm{V}_{\text {co }}$ can be calculated.

$$
\begin{gathered}
V_{a o}=\frac{V_{d}}{2} S F_{1_{a}} \\
V_{b o}=\frac{V_{d}}{2} S F_{1_{b}} \\
V_{c o}=\frac{V_{d}}{2} S F_{1 c}
\end{gathered}
$$

Then the inverter line-to-line voltage can be derived as follows:

$$
\begin{aligned}
& V_{a b}=V_{a o}-V_{b o} \\
& V_{b c}=V_{b o}-V_{c o} \\
& V_{c a}=V_{c o}-V_{a o}
\end{aligned}
$$

In order to calculate the phase voltage $\mathrm{V}_{\text {no }}$ is needed as shown below:

$$
\begin{aligned}
& V_{n o}=\frac{1}{3}\left(V_{a o}+V_{b o}+V_{c o}\right) \\
& V_{a n}=V_{a o}-V_{n o} \\
& V_{b n}=V_{b o}-V_{n o} \\
& V_{c n}=V_{c o}-V_{n o}
\end{aligned}
$$

Assuming the load consists of a balanced R-L load, the load currents can be determined as a ration of the phase voltage and the respective impedance as given below:

$$
\begin{aligned}
& I_{a}=\frac{V_{a n}}{Z_{a}}=\frac{V_{a n}}{R+j \omega L} \\
& I_{b}=\frac{V_{b n}}{Z_{b}}=\frac{V_{b n}}{R+j \omega L} \\
& I_{c}=\frac{V_{c n}}{Z_{c}}=\frac{V_{c n}}{R+j \omega L}
\end{aligned}
$$

The switch currents are calculated by the product of the load currents with the corresponding switching function $\mathrm{SF}_{2 \mathrm{a}, \mathrm{b}, \mathrm{c}}$.

$$
\begin{aligned}
& I_{S 1}=I_{a} * S F_{2} a \\
& I_{S 3}=I_{b} * S F_{2 b} \\
& I_{S 5}=I_{c} * S F_{2 \_c}
\end{aligned}
$$

Using all of these equations VSI can be modeled accurately. The developed model is then tested for various loading conditions. Input in the form of $\mathrm{P}$ and $\mathrm{Q}$ are 
dynamically changed and the VSI output (voltage and current) and efficiency is evaluated.

\section{Fuel Cell Generator and VSI with Controllers}

To meet the requirements for interconnecting a fuel cell system to a utility grid and control the real and reactive power flow between them, it is necessary to shape and control the inverter output voltage in amplitude, angle, and frequency. In this section, a PWM controller is designed for the inverter to satisfy voltage regulation as well as to achieve real and reactive power control. To this end, a d-q transformation is used to transfer a stationary $(\mathrm{abc})$ system to a rotating (dq0) system. The transformation decreases the number of control variables from 3 to 2 (component 0 will be zero) if the system is balanced. The d-q signals can also be used to achieve zero tracking error control. In order to determine the error, or difference between the reference signal and the actual signal a reference voltage is needed. To calculate the reference signal a set of equations are used below.

$$
\begin{gathered}
V_{\text {ref }}=\frac{Z^{2}}{E^{2}}\left(P^{2}+Q^{2}\right)+E^{2}+2 \mathrm{PZ} \cos \left(\theta_{Z}\right)+2 Q Z \sin \left(\theta_{Z}\right) \\
\delta=\theta_{Z}-\cos ^{-1}\left\{\frac{Z P}{E V_{S}}+\frac{E}{V_{s}} \cos \left(\theta_{Z}\right)\right\}
\end{gathered}
$$

Where $\mathrm{V}_{\text {ref }}$ and $\delta$ would then need to be transformed into dq coordinates (abc/dq), and this is done by using the matrix equation as in (42). As a part of the overall control architecture a voltage and current controller was designed. Fig. 6 illustrates the design and control topologies of a VSI inverter implementation.

$$
\left[\begin{array}{l}
V_{d} \\
V_{q} \\
V_{0}
\end{array}\right]=\left[\begin{array}{ccc}
\cos (\theta) & \cos \left(\theta-\frac{2 \pi}{3}\right) & \cos \left(\theta+\frac{2 \pi}{3}\right) \\
\sin (\theta) & \sin \left(\theta-\frac{2 \pi}{3}\right) & \sin \left(\theta+\frac{2 \pi}{3}\right) \\
\frac{1}{\sqrt{2}} & \frac{1}{\sqrt{2}} & \frac{1}{\sqrt{2}}
\end{array}\right]\left[\begin{array}{l}
V_{a} \\
V_{b} \\
V_{c}
\end{array}\right]
$$

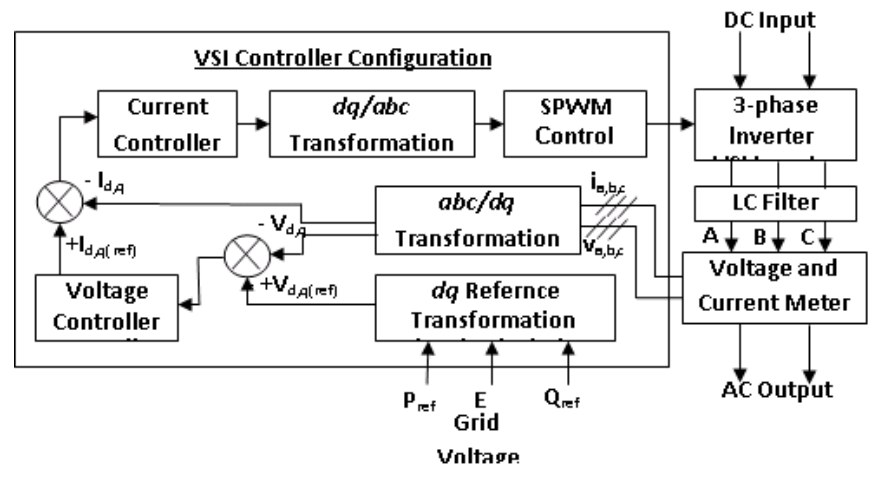

Figure 6. Flow diagram of a VSI controller

Once the signal passes through the voltage and current controllers it must be passed through a dq/abc transformation so the signal can be used in the SPWM. The transformation is designed based on (43). A voltage and current controller is designed for internal control of the inverter. Fig. 7 shows the block diagram of the current and voltage controller that has been used. After the design and modeling of the inverter, the system is tested with inverter and power conditioning devices.

$$
\left[\begin{array}{l}
V_{a} \\
V_{b} \\
V_{c}
\end{array}\right]=\left[\begin{array}{ccc}
\cos (\theta) & \sin (\theta) & \frac{1}{\sqrt{2}} \\
\cos \left(\theta-\frac{2 \pi}{3}\right) & \sin \left(\theta-\frac{2 \pi}{3}\right) & \frac{1}{\sqrt{2}} \\
\cos \left(\theta+\frac{2 \pi}{3}\right) & \sin \left(\theta+\frac{2 \pi}{3}\right) & \frac{1}{\sqrt{2}}
\end{array}\right]\left[\begin{array}{l}
V_{d} \\
V_{q} \\
V_{0}
\end{array}\right]
$$
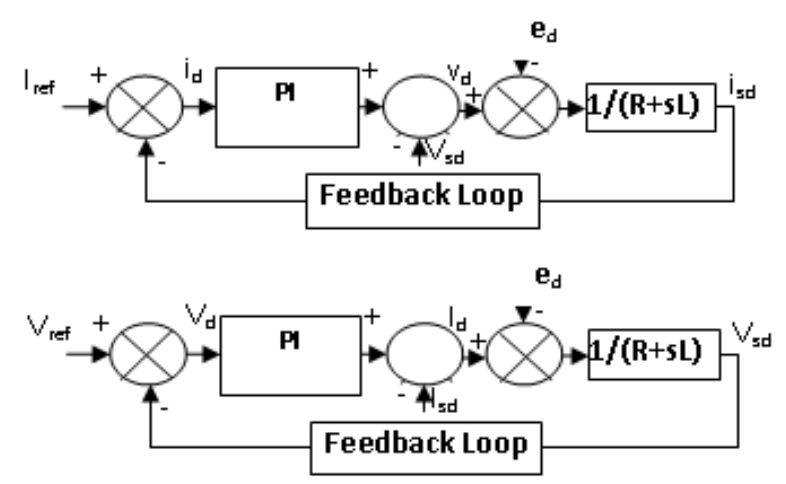

Figure 7. (a) Current controller block diagram (b) Voltage controller block diagram

\section{MOdELING IN MATLAB ${ }^{\circledR}$ AND SIMULINK ${ }^{\circledR}$ AND SIMULATION RESULTS}

\section{A. Fuel Cell Generator}

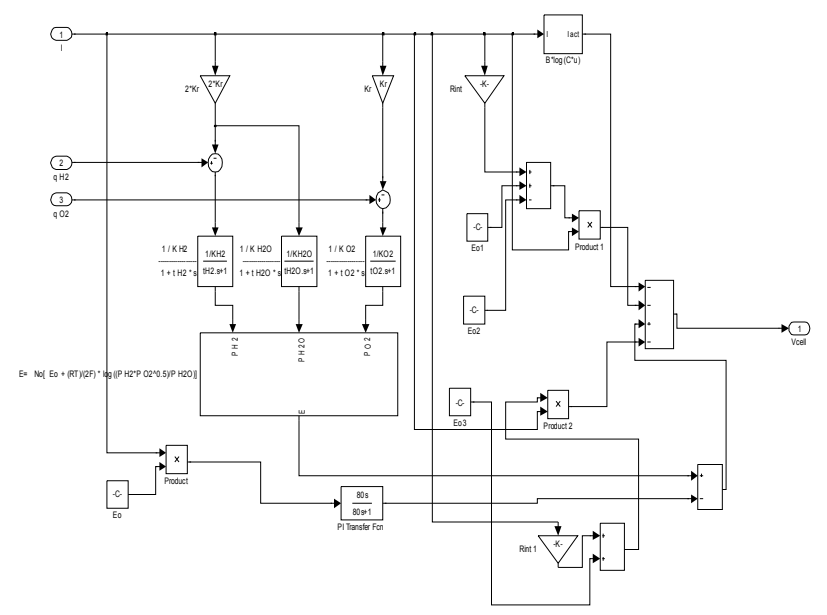

Figure 8. Detailed model of a fuel cell stack

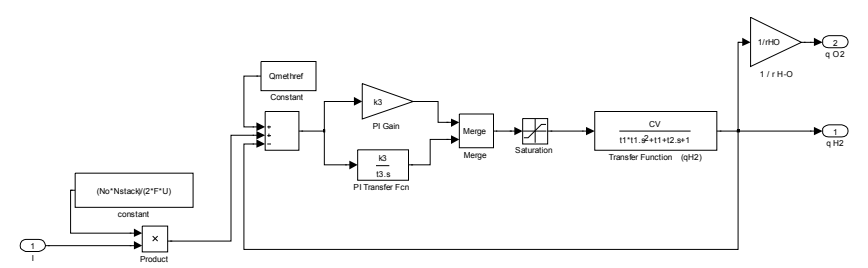

Figure 9. Detailed model of a fuel cell reformer

The proposed models are all implemented using MATLAB $^{\circledR}$ and Simulink ${ }^{\circledR}$. A detailed model developed using 
MATLAB $^{\circledR}$ and Simulink $^{\circledR}$ for a fuel cell generator and reformer is in fig. 8 and fig. 9. There is only one input and two outputs to the fuel cell generator and they are feedback current, DC output voltage, and hydrogen flow rate respectively. The feedback current will vary depending on the load demand and the hydrogen flow rate will vary depending on the feedback current. The voltage is a function of the feedback current, partial pressures of hydrogen and oxygen, and the over voltage potential inside the fuel cell.

The fuel cell generator model shown in these figures is then tested with step changes in the feedback current as shown in fig. 10. For this test case, the generator is assumed to be in the active mode. The results of this simulation show that as the feedback current increases fuel cell voltage decreases. The increase in current increases methane flow rate and hydrogen flow rate as well. All of which has a small time delay before reaching steady state. For the variations in $\mathrm{P}$ and $\mathrm{Q}$, the fuel cell model responded well. The tests are then compared with the datasheet of a $1 \mathrm{KW}$ active fuel cell that has been purchased. The model validation proves that the nonlinear model is accurate and can be used for further analysis of FC based micro grid and smart controller designs. Also this modeling methodology has shown improvements with respect to other models that did not use, $\mathrm{V}_{\text {ohm }}$ and $\mathrm{V}_{\text {conc }}$ in the fuel cell generator. In conclusion, this model is able to accurately simulate the transient response of a real PEM fuel cell generator.

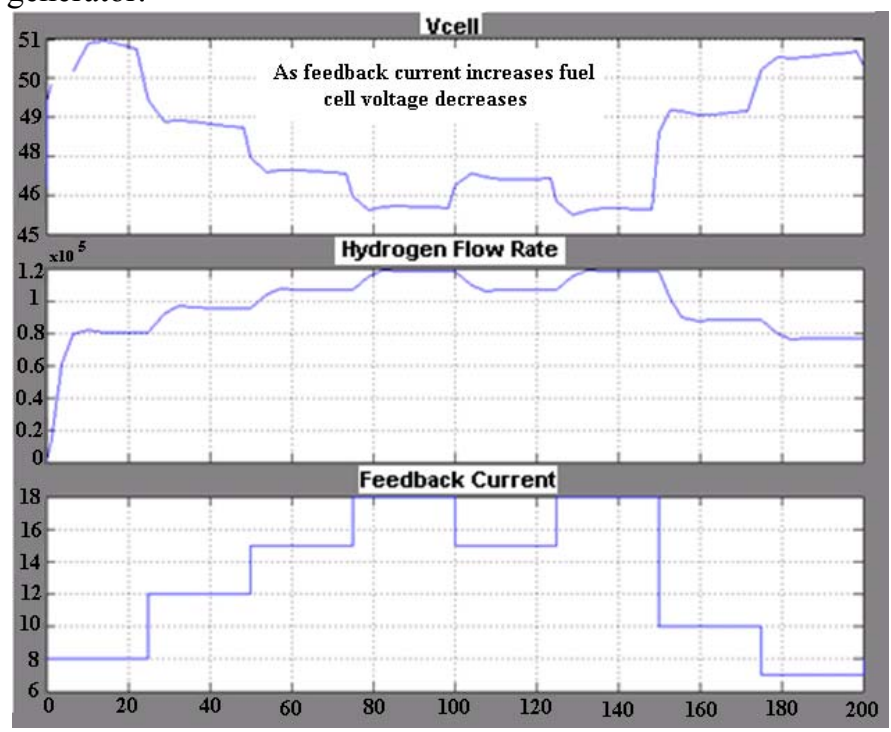

Figure 10. Results from fuel cell generator simulation

\section{B. DC/DC Converter and Overall Fuel Cell Generator}

The next step is to integrate the power conditioning devices with the nonlinear fuel cell model. The DC/DC converter detail model uses the values as in Table 1. These values are designed for the simulation and integration with the fuel cell generator. The simulation and control strategies required to integrate the converter and fuel cell model generates these values.

TABLE 1: CONVERTER PARAMETERS

\begin{tabular}{llll} 
Sym. & Parameter & Value & Unit \\
\hline $\mathrm{R}_{\mathrm{L}}$ & Input Port Resistance & 0.05 & $\Omega$ \\
$\mathrm{I}_{\text {gw }}$ & Switching Loss Current & 0.03 & $\mathrm{~A}$ \\
$\mathrm{~V}_{0}$ & Desired Reference Output Voltage & 240 & $\mathrm{~V}$ \\
$\mathrm{I}_{c}$ & Desired Reference Input Current & 20 & $\mathrm{~A}$ \\
$\mathrm{~F}_{5}$ & Switching Frequency & 5000 & $\mathrm{~Hz}$ \\
$\mathrm{R}$ & Resistance & 4.6 & $\Omega$ \\
$\mathrm{P}_{0}$ & Max Power Output & 500 & $\mathrm{~W}$
\end{tabular}

Fig. 11 shows a simulation results performed integrating fuel cells and DC/DC converter using a variable resistive load to test the dynamic response of the fuel cell and converter together with a purely resistive load demand.

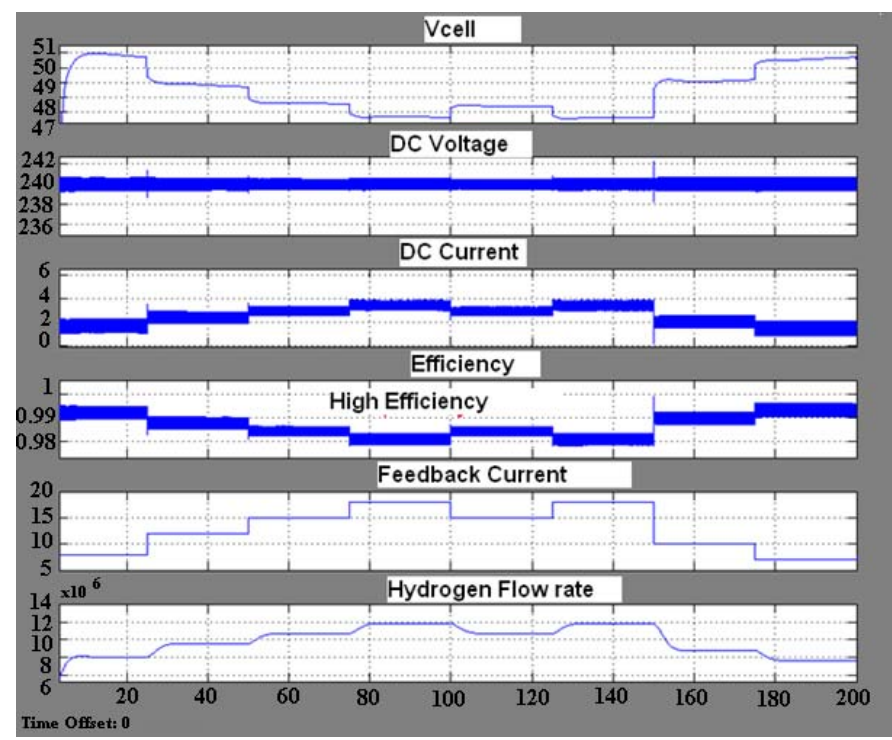

Figure 11. Results from fuel cell generator and DC/DC converter simulation

The resulting plots show that a varying converter input voltage and current results in a constant converter output voltage. The duty cycle changes to accommodate the load demand and thus the efficiency stays high.

\section{Fuel Cell Generator as a Micro-Grid}

To ensure the correct response of the micro-grid, several case studies are performed. The parameters and the values used for the VSI inverter are as shown in table 2. The objective of this case study is to discuss the FC working as a micro grid with varying load under the control of VSI inverter controller and FC controller.

\begin{tabular}{llcl}
\multicolumn{4}{c}{ TABLE 2: INVERTER PARAMETERS } \\
Svm & \multicolumn{1}{c}{ Parameter } & Value & Unit \\
\hline $\mathrm{F}$ & Frequency & 60 & $\mathrm{~Hz}$ \\
$\mathrm{~F}_{5}$ & Switching Frequency & 1000 & $\mathrm{~Hz}$ \\
$\mathrm{~V}_{\text {to }}$ & Three-Phase Voltage & 480 & $\mathrm{~V}$ \\
$\mathrm{Z}$ & Impedance & 0.5 & (R per unit) \\
$\mathrm{L}$ & Inductance & 0.05 & (L per u'it)
\end{tabular}




\section{A. Case Study}

Following illustration shows a case study for a light loaded distribution grid. In this case the system will also be required to deliver reactive power to the grid to help boost the grid voltage. The study is performed with a resistive and reactive load demand, considered to be light loading for this system. The excessive reactive power can be consumed by the distribution Grid system (i.e. $\mathrm{Q}<0$ ). The inputs are constants and initially considered hard switching so some sharp oscillations before it goes to a steady state are expected (Fig. 12 and fig. 13). The results indicated that the model stabilizes with high efficiency, and accurate output voltage with changing inputs.

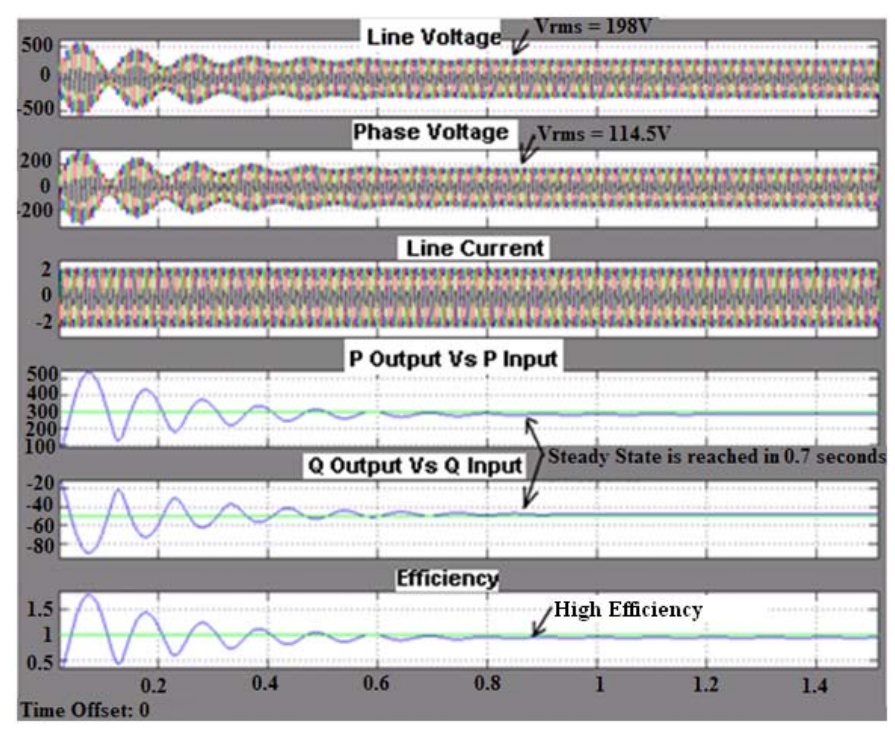

Figure 12. Results from light loaded DC/AC inverter simulation

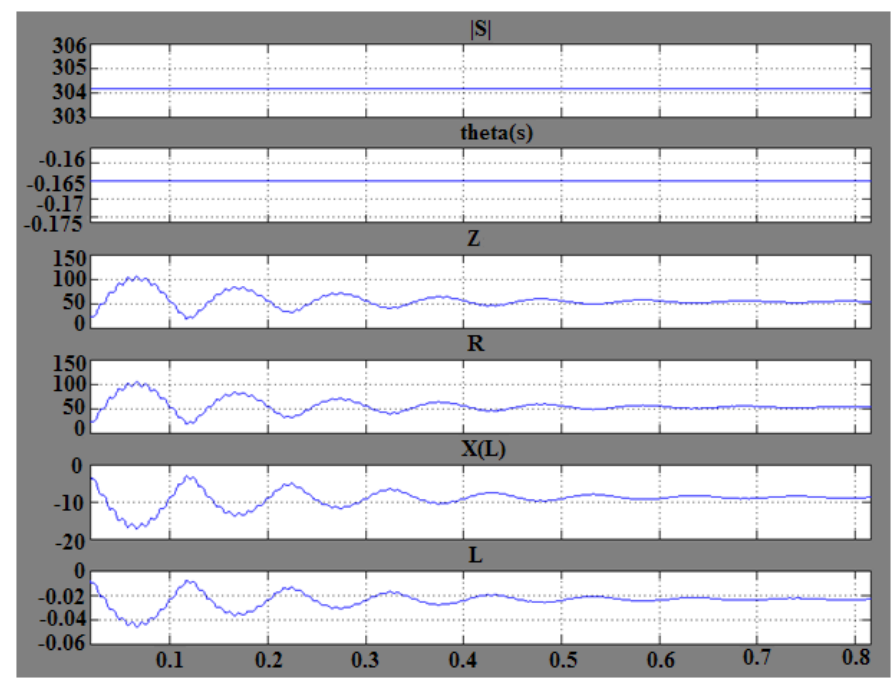

Figure 13. Load impedance, Resistance, Reactance, Inductance, and Complex Power as seen by the output of the inverter.

Simulation results (fig.14 and fig.15) of this case shows that the control signals respond to the real and reactive power demanded from the fuel cell system to the utility grid. Using the control signals the power delivered to the grid can be controlled as desired while the dc bus voltage is maintained well within the prescribed range. The results also show that the fuel cell system is capable of load-following and can remain stable under the occurrence of severe faults. It is noted that a two-loop inverter control scheme has an advantage over a voltage-only control scheme for the inverter on fault protection and system stability. Also fig. 14 shows the changes in the micro grid model with respect to real and reactive power of the load.

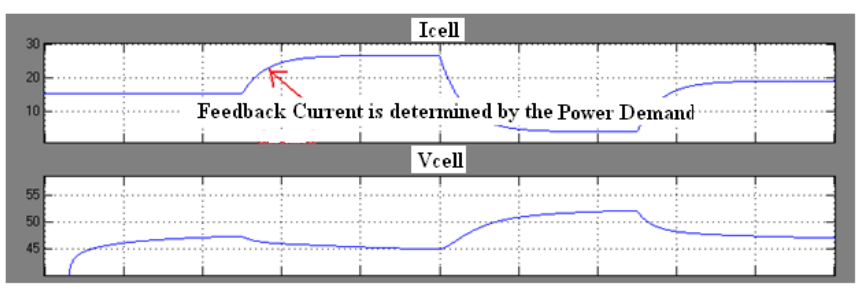

Figure 14. Fuel cell controller output feedback current

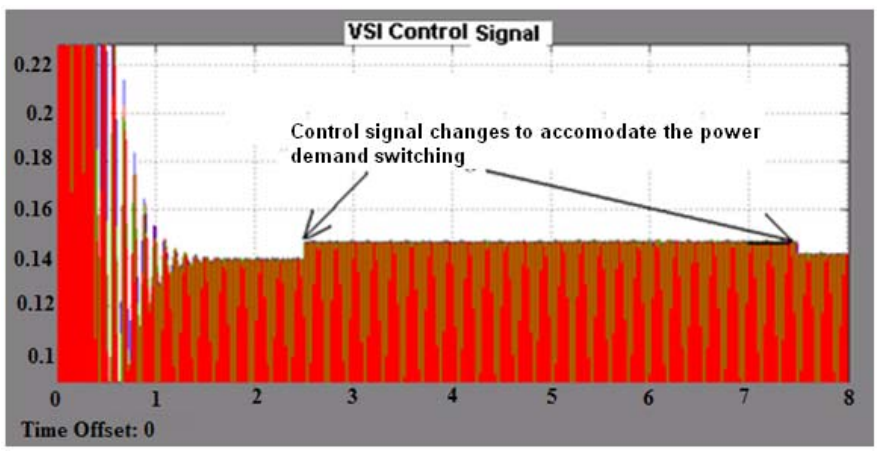

Figure 15. VSI control output feedback signal going to SPWM

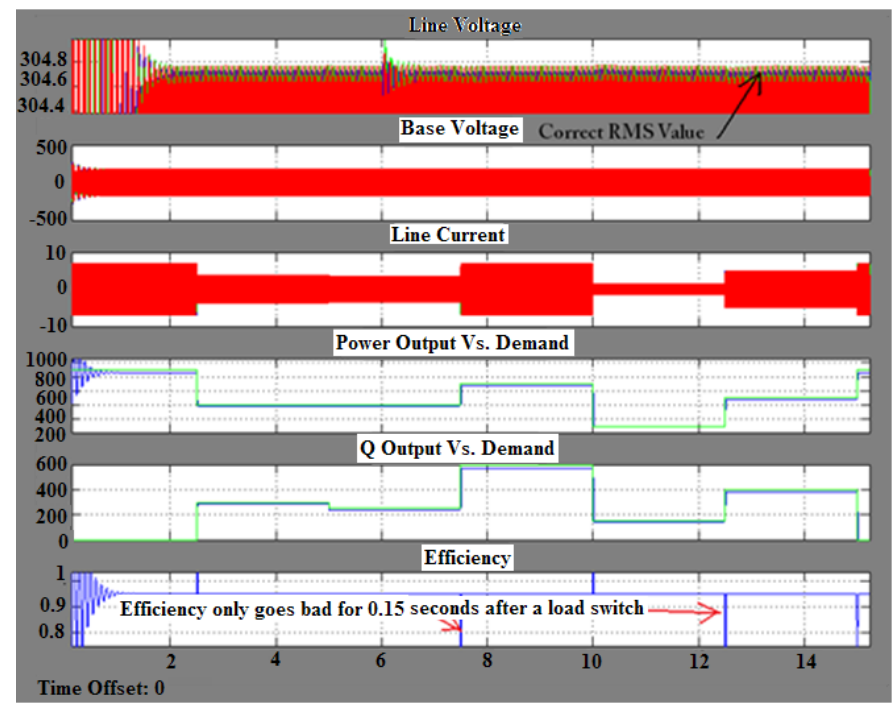

Figure 16. Micro grid system parameters with change in load

Fig. 16 show the detail analysis of testing the inverter $\mathrm{DC} / \mathrm{DC}$ converter and the fuel cell in the closed loop. As it is clearly visible the inverter model works well with changing 
load current producing highest efficiency and nominal voltage. After testing the inverter, overall system is analyzed as discussed next.

\section{CONCLUSION}

This paper illustrates the nonlinear modeling of fuel cell with power conditioning devices such as converter and inverter. The overall model will work as a fuel cell based micro-grid and can be integrated with the mega power grid. The simulation results exactly matches with the real-time results and the controllers designed shows substantial contribution in getting a steady output from the micro-grid. Currently the model and controller validations and performed with a real-life $1 \mathrm{KW}$ fuel cell kit.

\section{ACKNOWLEDGMENT}

Authors would like to thank National Science Foundation for the partial support for this project with award \# 0748238 awarded to the first author.

\section{REFERENCES}

[1] M.Y. El-Sharkh, A. Rahman, M.S. Alam, A.A. Sakla, P.C. Byrne and T. Thomas, "Analysis of Active and Reactive Power Control of a Stand-alone PEM Fuel Cell Power Plant," IEEE Trans. Power Systems, Vol. 19, Issue 4, pp. 2022-2028, November 2004.

[2] M. A. Laughton, "Fuel cells," Power Eng. J., vol. 16, no. 1, pp. 37-47, Feb. 2002.

[3] S. Um, C.Y. Wang, K. S. Chen, "Computational fluid dynamics modeling of proton exchange membrane fuel cell," Journal of Power Electrochemical Society, vol. 147, no.12, pp. 4485 4493, 2000.

[4] D. Singh, D.M. Lu, N. Djilani, "A two-dimension analysis of mass transport in proton exchange membrane fuel cells," Int. J. Eng. Sci., vol. 37, pp. 431-452, 1999.

[5] J. C. Amphlett, R.F.Mann, B.A. Peppley, P.R. Roberge and A. Rodrigues, "A model predicting transient response of proton exchange membrane fuel cells," J. Power Sources, vol. 61, pp. 183- 188, 1996.

[6] J. Padulles, G.W. Ault, J.R. McDonald, "An integrated SOFC plant dynamic model for power systems simulation," J. Power Sources, vol. 86, pp. 495-500, 2000.

[7] M. Y. El-Sharkh, A.Rahman, M.S. Alam, P.C. Byrne, A.A. Sakla and T. Thomas, "A dynamic model for a stand-alone PEM fuel cell power plant for residential application," J. Power Sources, June 2004.

[8] K. Hauer, "Analysis Tool for Fuel Cell Vehicle Hardware and Software (Controls) With an Application to Fuel Economy Comparisons of Alternative System Designs," Ph.D. dissertation, Dept. Transportation Technol. and Policy, Univ. California, Davis, CA, 2001.

[9] C. J. Hatziadoniu, A.A. Lobo, F. Pourboghrat, M. Daneshdoost, "A simplified dynamic model of grid-connected fuel-cell generators" IEEE Trans. Power Delivery, vol. 17, pp. 467-473, Apr. 2002.

[10] J. Hamelin, K. Agbossou, A. Laperriere, F. Laurencelle, T.K. Bose, "Dynamic behavior of a PEM fuel cell stack for stationary applications,” Int. J. Hydrogen Energy, vol. 26, No.6, pp. 625-629, 2001.

[11] M. Uzunoglu and M.S. Alam, "Dynamic Modeling, Design, and Simulation of a Combined PEM Fuel Cell and Ultracapacitor System for Stand-alone Residential Applications," IEEE Trans. on Energy Conv., Vol. 21 Issue 3, pp. 767-775, September 2006.

[12] M.Y. El-Sharkh, A. Rahman and M.S. Alam, "Neutral Network-based Control of Active and Reactive Power of a Stand-alone PEM Fuel Cell Power Plant," Journal of Power Sources, Vol. 135, pp. 88-94, 2004.

[13] F. Abdous, "Fuel Cell/DC/DC Converter control by sliding Mode Method" Proceedings of world academy of Science, Engineering and Technology, Vol. 37, January 2009.

[14] C. Wang, M.H. Nehrir, S.R. Shaw "Dynamic Models and Model Validation for PEM Fuel Cells Using Electrical Circuits" IEEE Trans on Energy Conversion, Vol.20, No. 2, pp. 442-451, June 2005.
[15] C. Wang, M.H. Nehrir, H. Gao "Control of a PEMFC Distribution Generation System" IEEE Trans on Energy Conversion, Vol.21, No. 2, pp. 586-595, June 2006.

[16] M. H. Rashid, Power Electronic - Circuits, Devices, and Application (Textbook), Pretence-Hall Inc, 2003.

[17] Mohan/Undeland/Robbins, Power Electronics - Converters, Applications, and Design 2nd Ed. (Textbook), John Wiley and Sons Inc., 1995.

[18] L. Ehsani, "A Simplified Functional Simulation Model for Three-Phase Voltage Source Inverter Using Switching Function Concept," IEEE Trans. On Industrial Electronics, Vol. 48 Issue 2, pp. 309-321, April 2001.

S. Kamalasadan (M' 05) received his Ph.D. in Electrical Engineering from the University of Toledo, Ohio in 2004, M.Eng in Electrical Power Systems

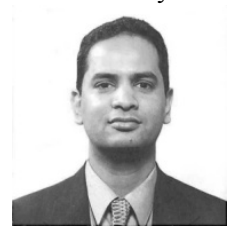
Management, from the Asian Institute of Technology, Bangkok Thailand in 1999 and B Tech. degree in Electrical and Electronics from the University of Calicut, India in 1991. He is currently working as an Associate Professor at the University of West Florida. $\mathrm{He}$ has won several awards including the NSF CAREER award. His research interests include Intelligent and Autonomous Control, Power Systems dynamics, Stability and Control, AI applications in control of Dynamic Systems and Real-time Embedded Systems Applications.

C. M. Tanton (SM' 07) received his BS degree from the University of West Florida in 2009. He is currently working as an employee in Eglin Air force Base. His research interests include Intelligent and Autonomous Control, Power Systems dynamics, Stability and Control. 